\title{
Laws Relating to Delivery of Bulk Oil Cargo with Regard to the Liability of the Carrier in Pakistan
}

\author{
Adeel Abid*
}

\author{
Surridge and Beecheno, Finlay House, I.I. Chundrigar Road, Karachi, Pakistan
}

\begin{abstract}
Maritime law is one of the ancient laws of the world and as such from the day of its commencement it joined the body of the international law and provides a legal frame work for rule of trade and commerce in international waters. The Shipping Laws are based on International Conventions and practices of maritime world, they require universal uniformity. The precedents and practices of maritime countries especially with reference to the liability of carrier with respect to the delivery of cargo can play an important role in the development and interpretation of local maritime laws of Pakistan. This article critically enlightens numerous landmarks judgment of Superior Courts and particularly refers to a judgment on the subject of bulk oil cargo which has been very well received in the United Kingdom, having been reported in the Lloyds Law Reports [1].
\end{abstract}

Keywords: Bill of lading, delivery, dictum, dry certificate, joint survey, ship's manifold, tolerance allowance, ullages.

\section{STATEMENT OF PROBLEMS}

Efforts are made in this article to study and highlight the pros and cons of the subject in the light of relevant provisions of the Maritime Law and the Judicial Pronouncement thereon specially in respect of delivery of Bulk Oil Cargo in Pakistan. The main problem is that the carrier/shipowners being wrongfully accused of short-landing of oil consignment due to theft and pilferage of oil cargo from the pipelines of the shore tank at the time of discharging the oil at Karachi. This is a critical analysis keeping in view the modern concept of the Maritime Law with special reference to Pakistani case laws Fig. (1).

\section{LIABILITY OF CARRIER}

It is very difficult in cargo claims to decide the cesser of liability of carrier at the port of discharge especially in cases of oil cargo claims, according to the shipping companies when the vessel arrives at the port of destination and discharges the entire quantity of cargo from the ship's into the shore tank then the liability of shipping companies just ceased as soon as the consignment discharged from the ship's manifold. According to the Article 1(e) of the Carriage of Goods by Sea Act, 1925 [2].

Article 1 (e) "Carriage of goods" covers the period from the time when the goods are loaded on the time when they are discharged from the ship.

In the case of Karachi Steam Navigation Co. Ltd v/s Abdul Rehman Abdul Ghani, [3] wherein it has been held by the full Bench of Dacca High Court as under:

Sched., Art. 1(e) - "Carriage of goods" - Definition Operation of act commences from time goods are loaded and continues till their discharge at destined port - Carrier

*Address correspondence to this author at the $3^{\text {rd }}$ Floor, Finlay House, I.I. Chundrigar Road, Karachi, Pakistan; Tel: +92(21) 32427292-4 \& 7; Fax:+92(21) 32416830 \& 32418298; E-mail: adeel77abid@yahoo.com showing that goods suffered damage after discharge at destined port - Quantum of damage not governed by Act but by a lawful stipulation between parties.

In the case of New Jubilee Insurance Co. Ltd v/s The United Oriental Steamship Co., [4] the Division Bench of Sindh High Court has been held as under:

Carrier's liability begins when goods loaded and ends when goods discharged from ship - Provision in bills of lading providing for cesser of liability of carrier as soon as goods from ship or free from ship's tackle - Not inconsistent with, or repugnant to, provisions of Act XXVI of 1925 or Rules framed there under.

The perponderant view, appears to be that the liability of a carrier for carriage of goods under the said Act is for the period from the time when the goods are loaded on to the ship up to the time when they are discharged from the ship and that a provision in the bills of lading providing for the cesser of liability of the carrier in respect of goods carried in his ship as soon as the goods have been discharged from the ship or are free from the ship's tackle, is not inconsistent with or repugnant to the provisions of the said Act or the Rules framed there under.

\section{DELIVERY/DISCHARGE}

The crux of matter is as to what point of time and place the delivery takes place to the consignee/importer. It is fact that the Terminal Operators are nominated by the consignee well before the arrival of the ship and upon arrival the consignments are discharged into the shore tanks of the nominated terminal by connecting the hoses to the ship's manifold and the entire quantity found on board by joint survey is completely discharged to the entire satisfaction of the surveyors and consequently upon visual and physical inspection of the various tanks of the ship a dry certificate is issued which leads to the irresistable conclusion that the entire quantity on board is in fact fully discharged from the ship Fig. (2). 


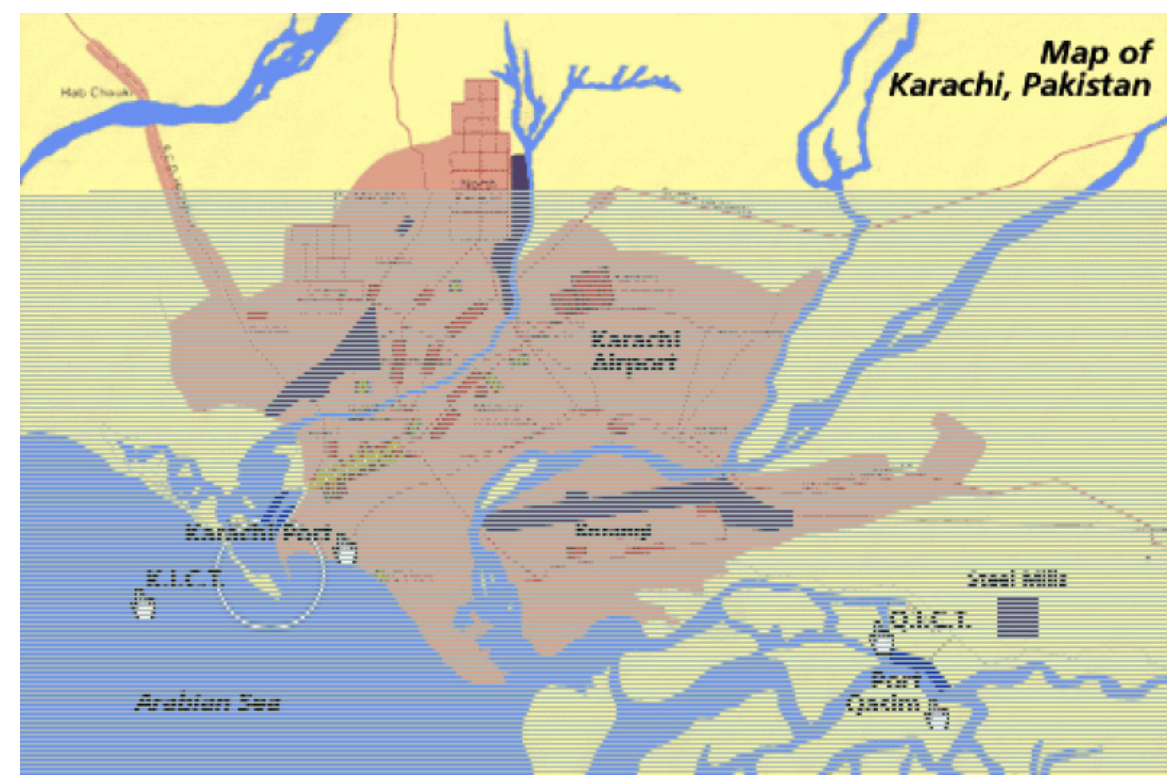

Fig. (1). Map of Karachi is attached herewith for the convenience of the reader which describes the location of two ports of Karachi i.e. Karachi Port and the Port Qasim.

Reliance is placed on New Zealand Insurance Co. Ltd v/s M.A. Rauf and Others, [5] where the word delivery occurring in Article III Clause (6) of the Schedule to the Carriage of Goods by Sea Act 1925 has been interpreted as equal to discharge appearing in Article III Rule (2) which is as follows [6]:

"2. Subject to the provisions of Article IV, the carrier shall properly and carefully load, handle, stow, carry, keep, care for and discharge the goods carried."

The omission of the word "Delivery" is most significant in the sense that it is not always possible for the carriers to deliver consignments directly to each of the numerous consignees, except in case of direct delivery cases where there is generally one receiver of the goods is involved. Reliance is placed on Marine Cargo Claims by William Tetley [7].

\section{DELIVERY}

\section{Introduction}

Article 3 (2) which outlines the principle of responsibility of the carrier under the Hague and Hague/ Visby Rules does not refer to "Delivery". The term is used nevertheless, in the Rules at Article 3(6) (notice of loss and time for suit) so that one must conclude by the normal rules of interpretation that the failure to mention delivery in Article 3(2) was purposeful.

It is stated that under the scheme of things it is incumbent upon the carrier to discharge the goods in to the custody of the person entitled under the law or practice of the port or as in the case of oil cargo, the nominee of the consignee i.e. the shore terminal.

The case of M.V. "ASIAN POLLUX" [8] has completely misunderstood the observation made by the Division Bench in the case of New Zealand Insurance Co. Ltd v/s M.A. Rauf and Others [9] by reaching to the conclusion that delivery means handed over to consignee which is in the nature of things wholly misconceived not contemplated by the Carriage of Goods by Sea Act.

Obviously no sooner the goods pass through the ship's manifold the ship or the carriers have no control whatsoever over transfer of custody of the goods to the shore tank who ought to be held accountable for the entire quantity thus taken over by them from the ship for the purpose of storage and distribution under a separate agreement between them and the consignee for consideration.

It is a remarkable feature of the entire transaction that although after transfer of custody of the entire quantity found on board and taken over by the shore terminal, the terminals are never held accountable, which proves to the hilt complicity between them and the consignee with the connivance of the customs officer and the surveyors, who are all mutually benefited. Through out the history of such transactions there has never been any claim alleged against the terminal and it is only the ship or their owners and their agents who are called upon to account for the alleged shortages and pay for them.

\section{MEASUREMENT OF OIL CARGO}

At the port of shipment in terms of the contract between the buyer and the seller the quantity required is predetermined and it is pumped from the shore tanks into the ships and the same contracted quantity finds place in the Bill of Lading, as declared by the shippers. Once the goods are shipped on board the measurement are taken by the Chief Officer and loaded quantity is determined. By way of caution the terminals usually ship a small quantity in excess so that on account of variable factors like the temperature, specific gravity etc, there may not be any short fall at the destination port. It is most remarkable that the large quantity shipped on board is comparable to the quantity found upon arrival on board before discharging and this method of ullages by which the quantities on board are determined is entirely reliable and most scientific and 


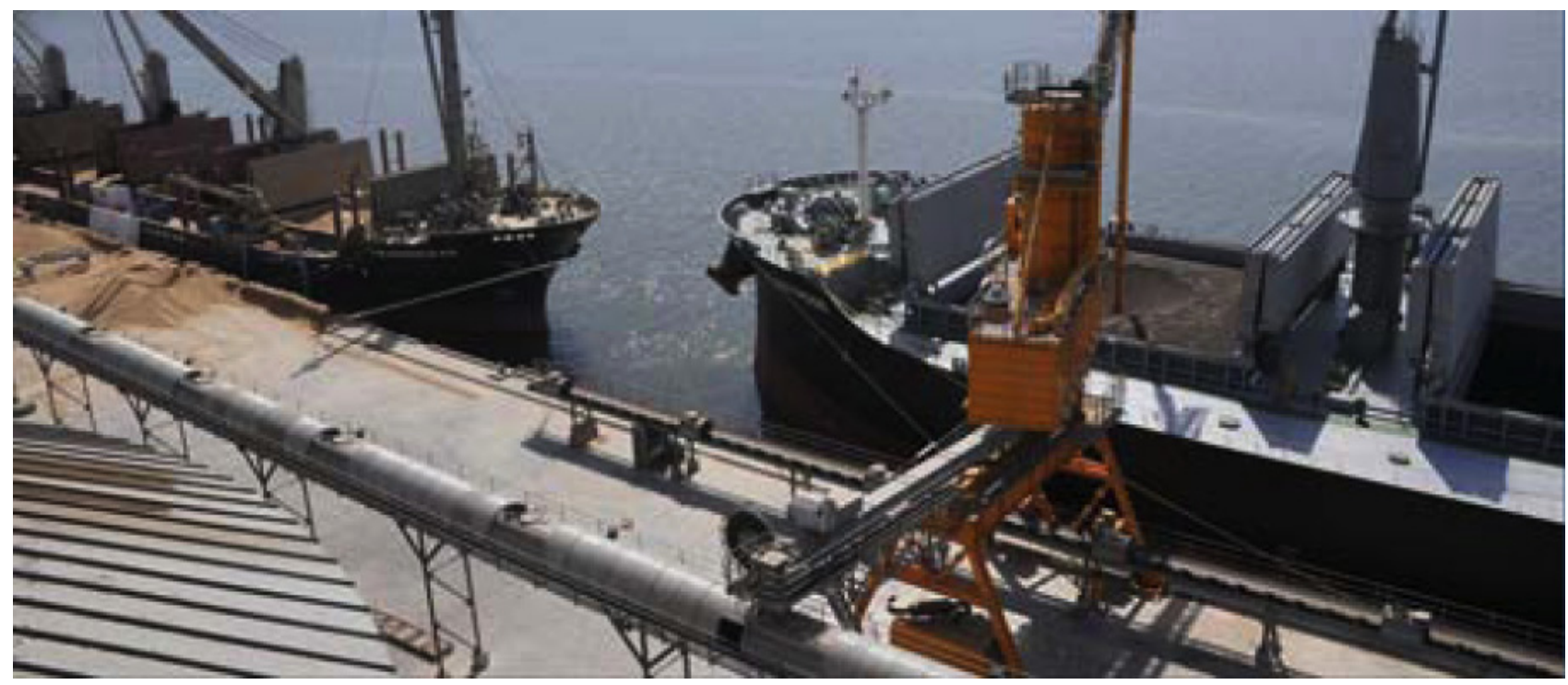

Fig. (2). Discharging operation at Karachi port.

cannot be brushed aside on the basis of a myth that due to the constant movement of the ship on account of the waves of the sea the ullages are entirely unreliable, as has been held in the case of Lady Helene [10]. The Collector of Customs challenged the said decision of the Division Bench in the Supreme Court of Pakistan in the case of Collector of Customs v/s Fatima Enterprise which was pleased on 4.11.2003 to direct that [11].

\section{“Operation of the Impugned Order is Suspended"}

By an order dated 30 ${ }^{\text {th }}$ March 2004 the Supreme Court of Pakistan was further pleased to grant leave to appeal in the case Collector of Customs v/s Fatima Enterprise [12] precisely for considering the effect of joint survey of the total arrived quantity found on board before discharging and the "dry certificate" issued by the surveyors after completion of discharging vis-a-vis the alleged shortage determined at the shore tanks. Thereafter, the judgment in Fatima Enterprise v/s Collector of Customs [13] was set aside by the Supreme Court by Order dated 05-04-2011.

It is stated with utmost respect that it is a matter of common knowledge that any liquid filled in any container does not move separately inside the container and a typical example is that while traveling in an aircraft at the speed say 300 miles per hour the beverages served on board do not spill out of the glass due to the movement of the aircraft at such high speed. It follows therefore that by its own tremendous weight the oil consignment shipped in the tanks of the ship does not move separately from the ship inside the tanks, with the result that the ullages taken are constant and entirely satisfactory and stable, and indeed this method is universally accepted as wholly satisfactory and there is no force in the argument that on account of the movement of the ship due to the waves the measurement on board is unreliable.

According to the usual practice the terminal calibration of the shore tanks is checked every seven years. By reason of tremendous weight of the cargo the soft reclaimed soil at the centre of the tanks, caves in and the calibration which are made at the walls of the tank cannot be accurate. Due to this reason the shore tank figures are unreliable. Some times the tanks hit on the sides which also upsets the calibration.

\section{LEAKAGE PILFERAGE AND THEFT}

It is pertinent to mention here that the pipeline systems are established, owned and maintained by the shore terminal at their own expense and without any control of the port or any authorities. It has further come on the record that the large number of incidents of theft tampering with the pipelines takes place and a substantial quantity of oil leaks in the process and/or is stolen with the active involvement or connivance of the security staff which however accounts for only a fraction of the shortage of the oil found at the terminal but the main shortages are on account of the quantities disappearing from the terminal before dips are taken Figs. (3-6).

For the convenience of the readers, it is better to illustrate with photographs which are annexed herewith for ready reference.

In this regard the reliance is placed on the principle laid down in the case of $\mathrm{M} / \mathrm{s}$. Trading Corporation of Pakistan v/s Inter-Continental Enterprises Corporation [14] wherein it has been held that if the arrived quantity of oil cargo delivered by the joint surveyor shows the cargo to be equal or more than the bills of lading quantity or comes within the tolerance allowance/limit and then dry tank certificate is available, the carrier will have no liability for any shortage discovered upon cargo being pumped into shore tank. However, most of the Honorable Judges of the Subordinate Courts do not follow the principle laid down in the land marks judgment of the Sindh High Court and decreed numbers of suits against the carrier by relying upon the shortage occur at the shore tanks. This demonstrates a very bad impression to the Protection and Indemnity (P\&I) Club and their Members due to which they have charged not only high freight to the importers but sometimes refuse to go their vessels within Pakistani jurisdiction in order to avoid frivolous proceedings. If serious steps will not be taken to avoid theft or pilferage the situation will be worst in future which ultimately affect the trade of Pakistan. 


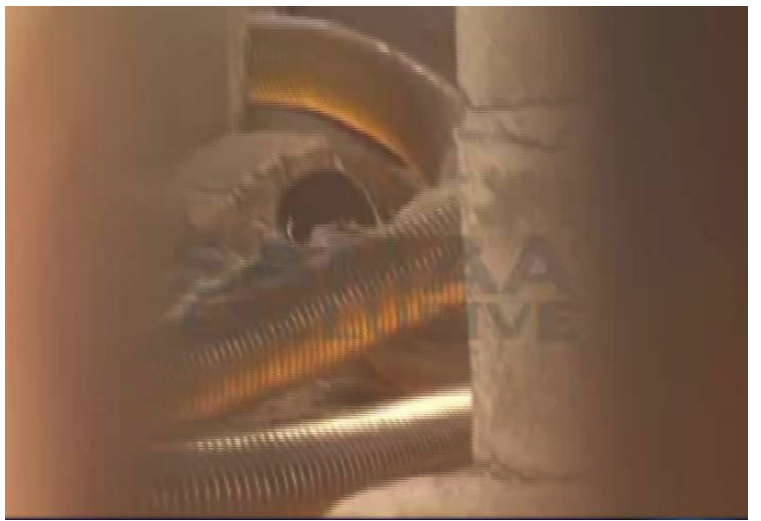

Fig. (3). Leakage from the pipelines at the port area of Karachi reported by the well known news channel of Pakistan.

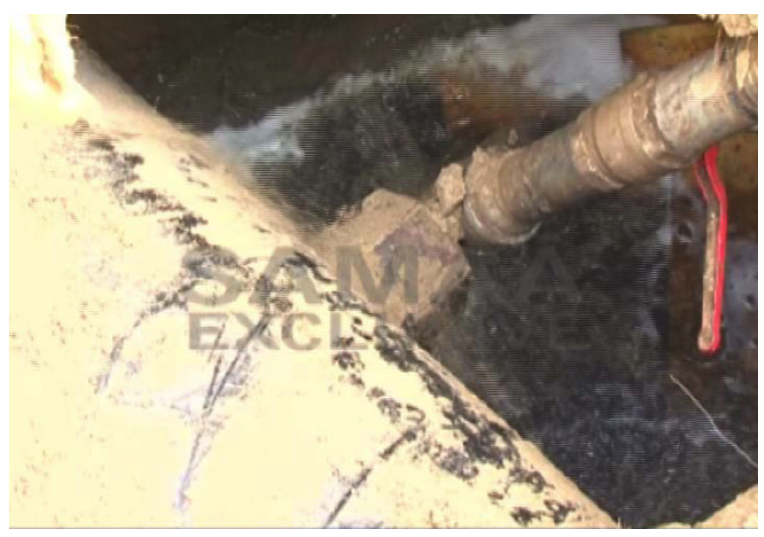

Fig. (5). Another view of leakage of oil from the shore pipelines.

\section{CONCLUSION}

In view of the land mark judgment of the Sindh High Court mentioned above the liability of carrier is ceased after discharging the oil consignment from the ship's manifold to the shore tanks which are appointed by the importers / consignees and the carrier have no control over there. Furthermore, it is the only judgment of any Superior Court of Pakistan in the country which has attempted to probe into causes of thousands of shortage of oil cases filed every year against every second or third ship or the owner and their Protection and Indemnity (P\&I) Clubs who eventually meet the liability simply perplexed as nearly full quantity of oil arrived on board mysteriously becomes short by couples of 100 tons, the moment it is transferred to the shore terminals and indeed any of those under whose very nose the oil disappears, is simply not willing to talk about it, the reason bring complicity as between them.

Therefore, it is high time for all concerns including Maritime Association of Pakistan as well as practitioners in the Shipping side to understand the real perception of Shipping laws relating to delivery of bulk oil cargo with regard to the liability of the carrier and strictly follow the land mark judgment of the Sindh High Court in order to meet the justice between the parties.

At the end it is hoped that the Law Department of the Government of Pakistan and the relevant concerned Authori-

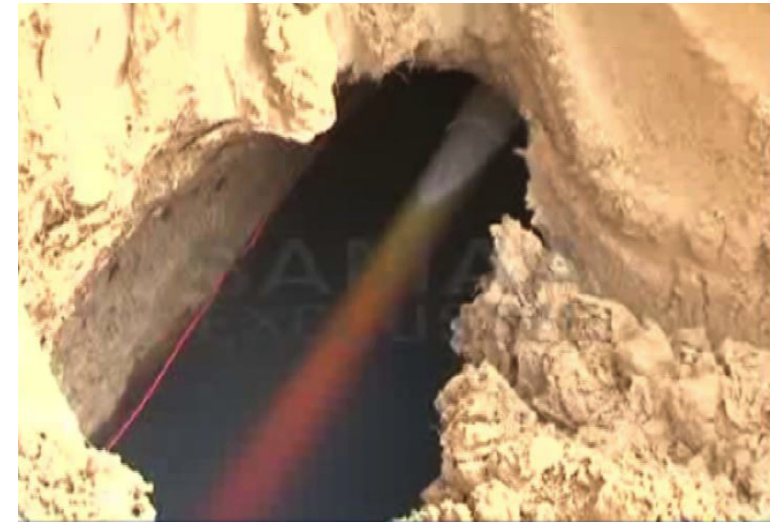

Fig. (4). Wastage of oil cargo from the underground pipelines.

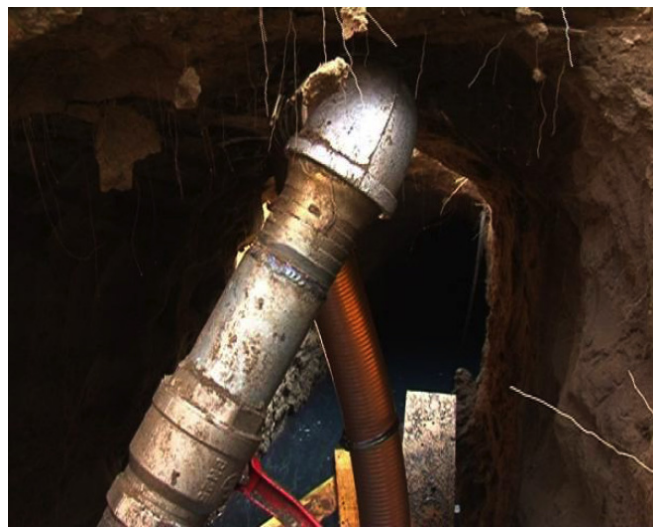

Fig. (6). Pilferage of oil during discharging of oil cargo.

ties will pay the required attention to take some immediate steps suggested as follows:

1. There is an urgent need for the Law Department of the Government to introduce amendments in the Carriage of Goods by Sea Act, 1925 specially introducing new provisions relating to bulk oil cargo.

2. Existing or prevailing Maritime Laws in Pakistan should be reviewed and updated so as to effectively protect the interest of Shipowners as well as importers.

3. Pakistan should immediately sign all the International Conventions relating to Shipping and allied subjects and incorporate their relevant provisions in the local laws for making uniformity among the comity of nation.

4. An appropriate amendment is to be introduced in the Carriage of Goods by Sea Act (COGSA), 1925 which protect the rights of shipowners against false claims as well as the right of recovery of small claimants.

5. Shipping laws should be introduced in the course of LLB which will develop understanding towards the subject and it also satisfies the needs of those who are practising in this field.

6. Strict checking must be required to control cases of theft and pilferage from the Port area.

7. The judgments of subordinate courts are decided in accordance with the dictum laid down by the Justice Shaiq Usmani reported in 2000 CLC 1892. 
8. Heavy cost should be imposed in order to discourage vexatious and frivolous litigations.

I deem this article will facilitate the legal fraternity so as to change for the betterment in the field of shipping laws in Pakistan and would also greatly facilitate the practice at the Bar.

\section{ABOUT THE AUTHOR}

The author is an experienced Maritime lawyer and research scholar, his field of specialization is Admiralty and Shipping. He is practicing on civil side and on maritime side since his inception in the profession and associated with the reputed law firm M/s. Surridge \& Beecheno.

\section{CONFLICT OF INTEREST}

The authors confirm that this article content has no conflict of interest.

\section{ACKNOWLEDGEMENTS}

Declared none.

\section{REFERENCES}

M/s Trading Corporation of Pakistan v/s Inter-Continental Enterprises Corporation. 2000 Lloyd's Report 563.

[2] Article 1(e) of the Carriage of Goods by Sea Act (Pakistan), 1925.
[3] Karachi Steam Navigation Co. Ltd v/s Abdul Rehman Abdul Ghani. Pakistan Law Digest (PLD) 1967 Dacca 159. www.pakistanlawsite.com

[4] New Jubilee Insurance Co. Ltd v/s The United Oriental Steamship Co., Pakistan Law Digest (PLD) 1975 Karachi 647. www.pakistanlawsite.com

[5] New Zealand Insurance Co. Ltd v/s MA Rauf and Others, Pakistan Law Digest (PLD) 1962 Dacca 31. www.pakistanlawsite.com

[6] Article III Rule (2) of the Carriage of Goods by Sea Act (Pakistan) 1925.

[7] Tetlay W. Marine Cargo Claims. $3^{\text {rd }}$ ed. Canada: International Shipping Publications 1988; p. 569.

[8] Nippon Yusen Kaisha (NYK) Lines v/s M/s MSC Textile (Pvt) Ltd \& Others, 2008 Corporate Law Digest (CLD) 492 \& Pakistan Law Digest (PLD) 2008 Karachi 244. www.pakistanlawsite.com

[9] New Zealand Insurance Co. Ltd v/s MA Rauf and Others, Pakistan Law Digest (PLD) 1962 Dacca 31. www.pakistanlawsite.com

[10] "LADY HELENE”, Sindh Baluchistan Law Report (SBLR) 2003 Sindh 1643, www.pakistanlawsite.com

[11] Order passed by the Supreme Court of Pakistan on 4th November, 2003 in the case of Collector of Customs v/s Fatima Enterprise (unreported).

[12] Collector of Customs v/s Fatima Enterprise, 2005 Supreme Court Monthly Review (SCMR) 1493.

[13] Order passed by the Supreme Court of Pakistan on 5th April, 2011 in the case of Collector of Customs v/s Fatima Enterprise (unreported).

[14] Justice Shaiq Usmani J, M/s Trading Corporation of Pakistan v/s Inter-Continental Enterprises Corporation, 2000 Civil Law Cases (CLC) 1892. www.pakistanlawsite.com

(C) Adeel Abid; Licensee Bentham Open.

This is an open access article licensed under the terms of the Creative Commons Attribution Non-Commercial License (http://creativecommons.org/licenses/by-nc/3.0/) which permits unrestricted, non-commercial use, distribution and reproduction in any medium, provided the work is properly cited. 